\title{
Supply disruption in the wake of COVID-19 crisis and organisational performance: mediated by organisational productivity and customer satisfaction
}

Ekpenyong Ekpenyong Udofia

Department of Business Administration, University of Lagos, Lagos, Nigeria

Bimbo Onaolapo Adejare

Department of Business Administration, School of Economics and Management, University of Minho, Braga, Portugal

\section{Gbemi Oladipo Olaore}

Department of Business Administration, Faculty of Business, Karabuk University, Karabuk, Turkey, and

Etete Ekpenyong Udofia

Department of Business Administration, University of Lagos, Lagos, Nigeria

\begin{abstract}
Purpose - This study aims to test the impact of the coronavirus (Covid-19) pandemic on large firms, with regard to a supply disruption, productivity, customer satisfaction and firm performance.

Design/methodology/approach - A cross-sectional survey design and stratified sampling technique were implemented for employee selection and data gathering. Confirmatory factor analysis (CFA) was used to examine the data and model fitness, while the structural equation model was used for hypotheses testing.

Findings - The pandemic triggered supply disruptions, but did not significantly impact the productivity of manufacturing firms directly. However, supply disruption positively and significantly impacted productivity. Organisational productivity had no significant impact on customer satisfaction, however, when mediating the relationship between Covid-19 and customer satisfaction, it produces a positive indirect effect. Finally, Covid19 and supply disruption when mediated by organisational productivity both had negative significant relationships on performance.

Research limitations/implications - Having a unique model, it creates a trail for future researchers to explore further. Though customer satisfaction was expected to be affected by the pandemic, it is interesting to find out that customer satisfaction when mediated by organisational productivity was positively influenced.
\end{abstract}

(C) Ekpenyong Ekpenyong Udofia, Bimbo Adejare, Gbemi Oladipo Olaore and Etete Ekpenyong Udofia. Published in Journal of Humanities and Applied Social Sciences. Published by Emerald Publishing Limited. This article is published under the Creative Commons Attribution (CC BY 4.0) licence. Anyone may reproduce, distribute, translate and create derivative works of this article (for both commercial and non-commercial purposes), subject to full attribution to the original publication and authors. The full terms of this licence maybe seen at http://creativecommons.org/licences/by/4.0/ legalcode
Wake of

COVID-19

crisis

Received 31 August 2020 Revised 1 December 2020 Accepted 13 December 2020 
JHASS
3,5

320

Practical implications - Disruptions are inevitable, managers must balance the pursuit of customer satisfaction and productivity so that one does not erode the other. Emphasis must be channelled towards managing the productivity of the firm to maintain customer satisfaction during these uncertain times. Deliberate steps like manufacturing flexibility investments should be initiated.

Originality/value - The first study to examine Covid-19, supply disruption, customer satisfaction, organisational productivity and performance in the Nigerian manufacturing sector.

Keywords COVID 19, Customer satisfaction, Manufacturing, Organisational productivity, Supply disruption

Paper type Research paper

\section{Introduction}

No one bargained for a disruption of this magnitude when they began the brand-new decade in 2020. The novel coronavirus (Covid-19) virus has brought in its wake an unprecedented supply chain disruption, the type you hypothesise, the type you simulate, but you never wish it actually happens. Disruption is said to occur when there is an unplanned stoppage in the movement of goods, both finished and work in progress goods within a supply chain (Revilla and Saenz, 2017). There is a growing interest in mitigating strategies to supply disruption as it, unfortunately, continues to rise (Jüttner and Maklan, 2011; Polyviou et al., 2019) especially in the manufacturing sector (Martins et al., 2019; Revilla and Saenz, 2017). As reported by the Business Continuity Institute (2011) 85\% of manufacturing firms have experienced supply chain disruption. In 2013, BCI (Business Continuity Institute, 2013) found that over a million euros loss recorded in single disruption incidents was high. Several million dollars in manufacturing disruption have been recorded in the last few years such as the Nissan disruption and the Land Rover disruption. Disruptions are caused by a variety of events; including natural disasters (Gunessee et al., 2017), delivery failure by suppliers (BCI, 2018), riots and protests (Pereira et al. Silva, 2014), loss/ withdrawal of financial capital (Hendricks and Singhal, 2003), plant-related issues (Marley et al., 2014), epidemics and disease (Natarajarathinam et al., 2009) and employee union strikes, (Addison and Hirsh, 1989), etc. Supply disruption has been said to have a great negative impact on productivity and performance as a whole (Marley et al., 2014). This is a special concern considering the magnitude of disruption that has been experienced in the last few months globally due to the Covid-19 virus. Over time, managers across the globe are asking for insights into strategies and methods to mitigate damage to production schedules in the face of disruptions (Kumar et al., 2020), the event of the Covid-19 pandemic simply amplified this need. Though there are a few studies that had investigated the relationship between special events, supply chain disruption and performance (Gunessee et al., 2017; MacDonald and Corsi, 2013; Babatunde, 2020), there is no study that has empirically researched the relationship between the Covid-19 pandemic, supply disruption, organisational productivity, customer satisfaction and organisational performance. This concern has inspired the research into the impact of supply disruptions on productivity, customer satisfaction and performance in Nigeria as a result of the Covid-19 pandemic.

\section{Literature review}

\section{Theoretical framework}

Systems theory. The systems theory is a theory that is applicable to several disciplines. It is a holistic approach to understanding a phenomenon (Mele et al., 2010). While the organisation might seem exclusive and independent, it is a part of a larger whole, the society and the interaction between them; if not carefully understood, might be the undoing of the organisation. Though the systems theory has been strongly linked to the ideals of Aristotle who believed that the study of parts would not produce the results of studying the sum 
(Bertalanffy, 1972), systems theory in management was made popular by the study of Kenneth Boulding in 1956 (published in the journal called Management Science), who tried to unravel how the systems thinking would apply to management and benefit industry practitioners (Boulding, 1956). The systems thinking was further emphasised by the philosophy of quality management in the 1960s, as Deming taught quality practitioners to view the pursuit of quality as an organisational task and all departments were interrelated in the quest for quality and superior performance to gain market share (Devor et al., 1992).

Though systems theory is quite extensive in the application and presents lacunas for management application research (Teece, 2018), it is widely accepted as a mainstay management theory in explaining the complexities in relationships within the organisation, as well as its interaction with the external environment (Bertalanffy, 1972; Cordon, 2013; Mele et al., 2010). This theory is very relevant to the study because the understanding of systems theory; being an interaction focus theory (Mele et al., 2010) gives meaning to the complex intricate tethered relationship between the occurrence of an event outside of managerial control in the external environment and an organisation, that is, how these events can affect suppliers/ customers and cause disruptions that affect the firm productivity and its customers. The understanding of systems theory will aid preparedness towards identifying events with such potential impacts and managing the ripple effects that come in its wake.

\section{Conceptual framework}

Supply disruptions in the wake of COVID-19. As globalisation spread and was embraced, so did supply chains. Supply chains are now across countries, regions and continents (Tse et al., 2016) and while supply chains expand and become incredibly complex, the risk of a supply disruption becomes inherent (Tang and Musa, 2011; Revilla and Saenz, 2017). The possibility of supply disruptions over the years for manufacturers has become a case of when, rather than if, leading to a growing interest in research within that sphere (Natarajarathinam et al., 2009; Marley et al., 2014; Ivanov et al., 2017; Kumar et al., 2015; Polyviou et al., 2019). While the country is dealing with the craziness that came with Covid-19, including the loss of life and the new way of living as we have experienced in the month of April. The manufacturing sector has been hit really badly because of its dependence on foreign firms for raw materials. An estimated $100 \mathrm{~m}$ dollars worth of supplies are stuck in China (Babatunde, 2020), this is a direct impact of suspended sea freights from China due to containment strategies. Studies show that the global economy relies on China, the origin of the novel virus, for a lot of its inputs. The United Nations, 2019 studies reveal that about a third of the world's production is made in China and transported to the world, Nigeria inclusive. This means that a virus that threatens China or Asia as a whole would have an expected adverse effect on manufacturers who relied on them for inputs. Unfortunately, the virus travelled around the world, affecting multiple countries simultaneously, bringing an unprecedented supply disruption across different industries in the manufacturing sector.

The Nigerian pharmaceutical industry amongst others has been an industry growing incapacity to produce, as it produces a significant portion of the pharmaceuticals in the Western African region (Wakeel and Ekundayo, 2016; Ikon and Chika, 2017). That said, the entire world's pharmaceutical manufacturers are heavily reliant on the Asian continent (specifically China and India) for their pharmaceutical raw materials (Ibis, 2020). It is expected that the pharmaceutical industry would be the most hit from the supply disruption caused by the Covid-19 novel virus. In a similar fashion, China also produces ninety percent of the world's intermittent parts for the creation of personal computers (PC), as well ninety percent of mobile phone supplies (McKinsey Global Institute, 2019). This means that whenever production in the Asian giant nation is grounded, the global manufacturing community of personal computers and mobile phones are gravely affected. Nigeria being one of the countries big on the 
JHASS 3,5

importation of these parts will also feel the brunt in these industries. In addition, China is also a majority producer in television parts and finished well. An estimated $70 \%$ of the global television parts are produced in China (McKinsey Global Institute, 2019), translating to tremendous supply disruption in the industry. China is also responsible for roughly $14 \%$ of Brazil's imports (Jenkins, 2012). With China working below par due to lockdowns across several cities, this will inevitably spark a supply disruption to manufacturers in Brazil.

The global textile and apparel industry is not left out of this disruption. In 2005 China was producing over a third of the world's textile (Shen, 2008), today, a report puts Chinese production at $53 \%$ of global production in textile and apparel, with the majority of this production going to other countries (McKinsey Global Institute, 2019), a reduction in the production of textile and apparel will spell supply disruption for several fashion firms in Nigeria and the world. Nigeria, being a major consumer of wheat-based consumer food is expected to also experience major supply disruptions in this industry. KPMG's (2016) report puts Nigeria as the 13th in line for wheat importations globally. The largest exporters of wheat are the European Union, Russia and the USA. All of them were severely hit by the novel virus, hence, an incredible reduction in production and an accompanying supply disruption to wheatbased consumer food producers around the world, especially in a country like Nigeria, where the majority of their material came from these countries with very severe death tolls.

Organisational productivity. Concerns over organisational productivity date back to the first scientific methods in management. Measuring and improving productivity is always at the heart of management goals because without it the organisation goes into losses (Shahiduzzaman et al., 2017). This is large because productivity drives the competitiveness of any firm (Dresh et al., 2018). Productivity is a rich blend of efficiency and effectiveness (Khan, 2003) and without it, there is no achievement of organisational goals in manufacturing firms (Ali et al., 2011).

Customer satisfaction. Customer satisfaction is an emotional response that validates the pleasure felt in consuming a product (Giese and Cote, 2000), it is the difference between successful firms and failed business establishments. In practical terms, the experiences and expectations of a customer form the fulcrum of his or her measurement of product performance and subsequent satisfaction or dissatisfaction (Emrah, 2010; Udofia, 2019). In other words, a very subjective exercise. As customer satisfaction is the bedrock of customer loyalty, which yields repurchase and higher market share (Gustaffsson et al., 2005), it is to be considered a paramount objective.

Organisational performance. The concept of performance is a commonly used word by management scholars and industry professionals (Bayo-Moriones $e t$ al., 2013) especially for the purpose of research that has to do with examining either employee and or organisation performance. This has made many researchers categorise organisation performance with elements such as productivity, profitability, efficiency and customer satisfaction (Gu and Jung, 2013; Gruber-Muecke and Hofer, 2015). Although, in the work done by Madrid et al. (2007) when performance is poorly measured by organisations, it leads to poor competitive positioning and results in a lack of sustainable competitive advantage. However, Murphy et al. (1996) as corroborated by (Gu and Jung, 2013) affirmed that the most commonly used measures of SMEs performance in literature are growth-efficiency and profitability. In the wake of the Covid-19 pandemic that has caused a global lockdown of the economy and restriction of international trading, the manufacturing sector today is struggling with some measures of performance such as productivity, customer satisfaction and profitability (Nkengasong and Mankoula, 2020). This is because manufacturing firms who produce at a large scale have now had to reduce production capacity especially those considered to be essential service producers, while all others are asked to shut down temporarily. The effect of these especially for those firms who have not been able to integrate technology into all their production and supply chain 
capabilities is reflecting in the company capacity to continue operations as a result of consistent production of goods and services leading to lack of customer satisfaction, revenue and profitability (Gruber-Muecke and Hofer, 2015; Nkengasong and Mankoula, 2020).

\section{Hypotheses development}

The role of China in the value chain of production cannot be over-emphasised. China recorded a major decline in its production by end of February 2020 as reported by the National Bureau of Statistics of China (UNCTAD, 2020). Though the Chinese Government shut down movements came sometime in February 2020, before that, there was the Lunar new year break in January that rolled over into the outbreak (Deloitte, 2020), in other words, an extended unplanned supply disruption. While China has cemented its place as the world's factory (Deloitte, 2020), a decline in work hours in China can pose problems for the productivity of those reliant on Chinese suppliers (UNCTAD, 2020). That said, the concern remains how much of an impact does the reduced production in China have on supplies and productivity for manufacturers in Nigeria, and how does supply disruption, in turn, impact organisational productivity and organisational performance as a whole. Epidemics being a major supply chain risk for firms with global networks is an interesting research context underexplored because of its rare occurrence. This prompted early simulations (Ivanov, 2020) to predict the impact of Covid-19 and the subsequent ripple effect on global supplies. The simulation results were a massive profit loss (90\%) for local manufacturers and supply disruption worldwide, however, a spread (across continents) will be accompanied by unprecedented supply disruption and major reductions across all performance indices for firms with global chains. Such predictions are yet to be empirically tested; thus, this study contributes to that growing literature of epidemic effect on manufacturing firms. The study of Ikon and Chika (2017) examined the impact of production constraint, specifically; material scarcity on organisational performance. It found a negative significant relationship. While the study focussed on the scarcity caused by the volatile economic environment, this study is a focus on disruptions caused by a pandemic and is a more robust understanding of the impact of material scarcity. Kumar et al. (2020) affirmed a negative impact of Covid-19 on organisational productivity, however, this result is yet to be substantiated across other countries and industries. A comprehensive literature review reveals that irrespective of industry focus, geographical region or methodologies, studies into the understanding of epidemic outbreaks on supply chains are of the essence (Queiroz et al., 2020), this discussion leads to the first four hypotheses of this study:

H1. There is a positive significant relationship between Covid-19 and supply disruption.

H2. There is a negative significant relationship between Covid-19 and organisational productivity.

H3. There is a negative significant relationship between supply disruption and organisational productivity.

H4. There is a negative significant indirect relationship between Supply disruption and organisation performance through organisational productivity.

Kumar et al. (2015) understudied supply chain disruption and company performance. The study revealed that firms in India understudy recorded a financial loss due to disruption. The study called for more investigation of disruption effects on the performance of organisations in developing nations. The relevance of the international market on organisational productivity was examined by Caliendo and Rossi-Hansberg (2012), and it was revealed that there is a positive impact on organisational productivity by its presence in the international markets. Therefore, this implies that the absence thereof, as witnessed by the presence of Covid-19 might hamper 
JHASS 3,5

productivity and by extension its performance. Irrespective of ample literature that highlights the relevance of achieving customer satisfaction and organisational productivity to unlock sustainable profit growth (Anderson et al., 1997; Tanninen et al., 2010), the investigation into the relationship between both variables are minimal (Lee $e$ t al., 2017), as well as their resulting impact on overall performance. Studies by Shehzadi et al. (2020) and Khan and Hashim (2020) evaluated customer satisfaction and firm performance in service firms (education and Tourism, respectively). Both studies revealed that Covid-19 triggered intensive social media content and information quality to sustain customer satisfaction, and customer satisfaction had positive impacts on performance through brand image and customer loyalty. Babatunde (2020) conducted an earlier study on Covid-19 impact on organisational performance in Nigeria, however, his finding (significantly negative) was largely domiciled in the aviation industry. An extension of this study would be that of Alonso et al. (2020) that focussed on the hospitality industry, as dictated by transportation. Its conclusion was massive shutdowns of hospitality firms as fostered by restricted movements. Shen et al. (2020) early investigations into the impact of Covid-19 on firm performance in China revealed a negative significant relationship, and the impact was mostly felt in service (catering, tourism and transportation) industries. However, because the study was conducted in the early parts of the second quarter to assess the first quarter, they were of the opinion that managers with foresight in other parts of the world will study the early trend and implement strategies to mitigate devastating impacts. While it is important to replicate their study in other climes and industries, it is also important to assess the proactive nature of managers in Nigeria (as the world was aware of Covid-19 in January) to implement strategies that will mitigate the impact of Covid-19 on firm performance as opined by Shen $e$ t al. (2020). Most of the early studies conducted on the pandemic and firm performance were focussed on service industries (Alonso, 2020; Babatunde, 2020; Shen et al., 2020). it is important to investigate the impact of Covid-19 across manufacturing industries. The performances of manufacturing firms are dictated by their productivity (Ali et al., 2011), however, there are factors outside the control of a firm that may affect their productivity and overall performance. It is important to identify these factors to better mitigate them. Also, studies on customer satisfaction are usually under normal circumstances, thus studies assessing their relationship with variables like organisational productivity and performance during a pandemic is a significant contribution to the body of knowledge in the field of management sciences:

H5. There is a positive significant relationship between organisational productivity and organisational performance.

H6. There is a positive significant relationship between organisational productivity and customer satisfaction.

H7. There is a negative significant indirect relationship between Covid-19 and organisation performance through organisational productivity.

H8. There is a negative significant indirect relationship between Covid-19 and customer satisfaction through organisational productivity.

H9. There is a positive significant relationship between customer satisfaction and organisational performance.

H1O. There is a negative significant indirect relationship between Supply disruption and customer satisfaction through organisational productivity.

H11. There is a negative significant relationship between supply disruption and customer satisfaction (Figure 1). 


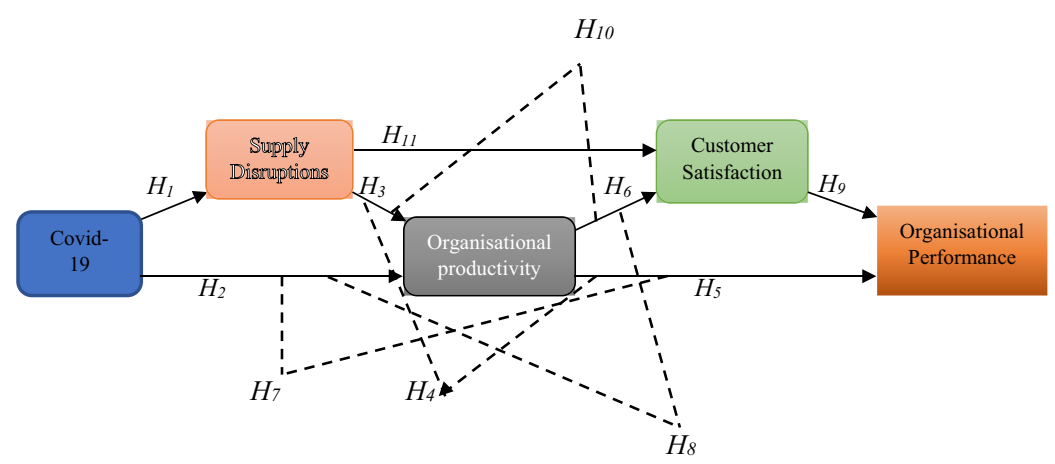

Wake of

COVID-19

crisis

325

- - - Indirect Relationships $\longrightarrow$ Direct Relationships

Figure 1.

Conceptual model

\section{Methodology}

A cross-sectional survey research design was used to gather the needed data as the study population comprises of employees within the manufacturing firms in Nigeria. In total,10 manufacturing firms with 500 staff and above were selected for sampling in the manufacturing industries and 100 employees (senior and management staff only) were selected from each firm making a total of 1,000 employees selected for sampling. The study used a stratified sampling method to prune down the type of organisation and respondents that could participate in the questionnaire response. To secure the interest of these firms in the various manufacturing industries, a mail was first sent to the management of about 32 firms requesting permission to include them in the research and only 16 firms showed interest to be part of the research. However, due to the selection criteria, only 10 firms were selected from amongst the 16 firms and 100 employees were selected from each of the 10 firms making a total of 1,000 respondents selected for sampling. Due to the Covid-19 pandemic that has brought about a social distancing policy all over the world, the questionnaire was drafted in a google form and the link was shared across the management and senior staffs of these manufacturing firms. The study collected responses from only 898 participants and the responses from these employees were then used for the analyses. Confirmatory factor analysis (CFA) was used to examine the data and model fitness and structural equation model was used to test the stated hypotheses in the study.

\section{Data analysis}

Two important steps are executed for the data analysis, and they involve the data-reduction step which involves the use of confirmatory factor analysis to prune the questionnaire items for each construct to a more sizeable model and data fitness. This is important for the second stage that involves testing the hypotheses with a structural equation model to examine the structural-relationship existing between variables (latent and observed).

\section{Measurement model}

Besides measurement items on Covid-19, the research instrument consisted of carefully adapted measurement items. Measurement items on supply disruptions were adapted from Chaudhuri et al. (2018) and Mishra et al. (2017). Items on organisational productivity were adapted from Kim et al. (2012), Lakhal et al. (2006), Grayson et al. (2016) and Zhang et al. (2000). Items on customer satisfaction were adapted from Lee et al. (2017), Chavez et al. (2016) and 


\section{JHASS 3,5}

Vasić et al. (2019). Finally, items on organisational performance were adapted from Kim et al. (2012), Tarí et al. (2007), Zhang et al. (2000), Yan et al. (2019) and Sadikoglu and Olcay (2014).

The measurement model is achieved through the data reduction stage using CFA. The measurement model, therefore, involves examining the construct validity to assess how each variable item fits the model. This involves conducting the reliability analysis, composite reliability and convergent validity. Cronbach alpha is the acceptable analysis for conducting reliability analysis for each variable in a study and having a figure from 0.70 and above is the acceptable recommended threshold (Amin et al., 2014). Hence, Table 1 shows the reliability analysis for each variable, and it is above the recommended threshold of acceptance. Similarly, convergent validity is the extent to which multiple constructs are in agreement at measuring the same models (Nusair and Hua, 2010). Convergent validity is measured using three approaches such as the calculation of normed fit index (NFI), factor

COVID 19 (COV)

COV1 Your country experienced positive tests of the novel Covid-19 virus

COV2 Your country has never experienced a pandemic of this magnitude

COV3 There is someone in your community/local government area that has tested positive

COV4 The Covid-19 virus is present in all parts of the country

COV5 Covid-19 virus has made a serious impact on the way we conduct business

COV6 Covid-19 virus protective guidelines are a big deal to my firm

COV7 Covid-19 has affected our suppliers' mode of operations

Supply disruption (SD)

SD1 We have experienced supply failures that affect production

SD2 There is shipment operations interruption that affecting deliveries

SD3 We experienced extended lead time at the supplier's end

SD4 There is a change in the price of raw materials

SD5 There is a change in the quality of raw material supplied

SD6 A key supplier has gone out of business

Organisational productivity $(O P)$

OP1 There is a significant improvement in our deliveries

OP2 There is a significant reduction in inventory waste levels

OP3 We have recorded improvements in cycle time

OP4 We have recorded reduced error rates and defect product

OP5 Our work design is continually improved

OP6 There is a significant reduction in product re-work hours

Customer satisfaction (CS)

CS1 I am happy with the company product quality in the last few months

CS2 They have delivered promptly in the last few months

CS3 Based on my recent experiences with the company I will recommend them

CS4 I remain loyal to the company product

CS5 When the need for products they produce arise, I will buy from them

CS6 Product price is satisfactory, considering the product quality

Organisational performance (ORP)

OPE1 There's a reduction in operating costs

Table 1.

OPE2 The conformance of finished goods to specification is very high

Research

OPE3

There is a significant increase in employee morale

measurement items
OPE4

We have recorded improved profitability

OPE5 Our new products differ substantially from our existing products
Chaudhuri et al., 2018

Chaudhuri et al., 2018

Mishra et al., 2017

Mishra et al., 2017

Mishra et al., 2017

Chaudhuri et al., 2018

Lakhal et al., 2006

Lakhal et al., 2006

Kim et al., 2012; Yan et al., 2019

Zhang et al., 2000; Grayson

et al., 2016

Grayson et al., 2016

Lakhal et al., 2006

Lee et al., 2017

Lee et al., 2017

Chavez et al., 2016

Chavez et al., 2016

Vasić et al., 2019

Chavez et al., 2016

Yan et al., 2019

Zhang et al., 2000

Sadikoglu and Olcay, 2014

Tarí et al., 2007

Kim et al., 2012 
loadings for each item and average variance extracted. The normed fit index as suggested by (Orçan and Yang, 2016) must be above 0.90 as the recommended threshold of acceptance and as shown in Table 1 , the NFI values for each construct are greater than 0.90 . Also, the factor loading for each item which is the second approach for measuring convergent validity must be above 0.50 as the minimum recommended values and given the value of 0.50 to 0.76 as shown in Table 1, hence, all items for the measurement model are beyond the acceptable values. Similarly, the average variance extracted for each variable as suggested by (Orçan and Yang, 2016; Nusair and Hua, 2010) must have values equal to or greater than 0.5. crisis

Furthermore, composite reliability is mostly used to examine the internal consistency of both the observed and latent variables in a study. Hence, a constructed value that is $\geq 0.70$ has internal consistency, and as shown in (Table 1), all five constructs have values between 0.705 and 0.728 (Tables 2 and 3 ).

Given the results in Table 2 above, the summary of the CFA results shows that the model perfectly fits the data set and is good to conduct the structural relationship existing amongst variables in the study using the structural equation model to test stated hypotheses. Furthermore, the literature supports that a GFI, CFI, IFI, NFI and TLI value that is above

\begin{tabular}{|c|c|c|c|c|c|c|c|}
\hline $\begin{array}{l}\text { Measurement } \\
\text { items }\end{array}$ & Constructs & CFI & NFI & Factor loading & $\begin{array}{l}\text { Cronbach's } \\
\text { alpha }\end{array}$ & $\mathrm{CR}$ & AVE \\
\hline $\begin{array}{l}\text { COV1 } \\
\text { COV2 } \\
\text { COV3 } \\
\text { COV4 } \\
\text { COV5 } \\
\text { COV6 } \\
\text { COV7 }\end{array}$ & $\begin{array}{l}\text { Covid-19 } \\
\text { pandemic }\end{array}$ & 0.917 & 0.908 & $\begin{array}{l}0.596 * * * \\
0.500 * * * \\
0.538 * * * \\
0.601 * * * * \\
0.631 * * * \\
0.563 * * * \\
0.588^{* * * *}\end{array}$ & 0.797 & 0.722 & 0.696 \\
\hline $\begin{array}{l}\text { SD1 } \\
\text { SD2 } \\
\text { SD3 } \\
\text { SD4 } \\
\text { SD5 } \\
\text { SD6 }\end{array}$ & $\begin{array}{l}\text { Supply } \\
\text { disruption }\end{array}$ & 0.924 & 0.910 & $\begin{array}{l}0.662^{* * * *} \\
0.763^{* * * *} \\
0.828^{* * * *} \\
0.704^{* * * *} \\
0.878^{* * * *} \\
0.862^{* * * *}\end{array}$ & 0.887 & 0.708 & 0.565 \\
\hline $\begin{array}{l}\text { OP1 } \\
\text { OP3 } \\
\text { OP4 } \\
\text { OP5 } \\
\text { OP6 }\end{array}$ & $\begin{array}{l}\text { Organisational } \\
\text { productivity }\end{array}$ & 0.910 & 0.921 & $\begin{array}{l}0.684 * * * \\
0.727 * * * \\
0.674 * * * * \\
0.637 * * * \\
0.791 * * *\end{array}$ & 0.832 & 0.728 & 0.603 \\
\hline $\begin{array}{l}\text { CS1 } \\
\text { CS2 } \\
\text { CS3 } \\
\text { CS4 } \\
\text { CS5 } \\
\text { CS6 }\end{array}$ & $\begin{array}{l}\text { Customer } \\
\text { satisfaction }\end{array}$ & 0.915 & 0.906 & $\begin{array}{l}0.607 * * * \\
0.735^{* * *} * \\
0.651^{* * * *} \\
0.528^{* * *} \\
0.630^{* * * *} \\
0.721^{* * * *}\end{array}$ & 0.810 & 0.705 & 0.715 \\
\hline $\begin{array}{l}\text { OPE1 } \\
\text { OPE2 } \\
\text { OPE3 } \\
\text { OPE4 } \\
\text { OPE5 }\end{array}$ & $\begin{array}{l}\text { Organisation } \\
\text { performance }\end{array}$ & 0.902 & 0.916 & $\begin{array}{l}0.573 * * * \\
0.681 * * * \\
0.653 * * * \\
0.691 * * * \\
0.601 \text { *** }\end{array}$ & 0.729 & 0.729 & 0.690 \\
\hline
\end{tabular}

Notes: CR: Composite reliability, AVE: Average variance extracted, CFI: Comparative fit indices, NFI: Normed fit index

Table 2. Measurement model 


\section{JHASS \\ 3,5}

\begin{tabular}{lccc}
\hline Indices & Threshold & Study results & $\begin{array}{l}\text { Accepted/ } \\
\text { not accepted }\end{array}$ \\
\hline Chi-square $\left(\mathrm{X}^{2} / \mathrm{DF}\right)$ & $<0.3$ & 2.425 & Accepted \\
TLI & $>0.9$ & 0.901 & Accepted \\
CFI & $>0.9$ & 0.921 & Accepted \\
GFI & $>0.9$ & 0.911 & Accepted \\
IFI & $>0.9$ & 0.908 & Accepted \\
NFI & $>0.9$ & 0.913 & Accepted \\
RMSEA & $<0.5$ & 0.053 & Accepted
\end{tabular}

Table 3.

Summary of CFA results
Notes: Where: $\left(X^{2} / \mathrm{DF}\right)=$ Degree of freedom/chi-square; NFI = Normed fit Index; TLI $=$ Tucker Lewis index; CFI = Comparative fit index; IFI = Incremental fit index; GFI = Goodness-of-fit index; RMSEA = Root mean square error of approximation

0.90 is acceptable and (Yana, 2007; Field, 2005) recommended for assessing model/data fitness at the data reduction stage and as shown in Table 2 that all the elements of CFA measures have a value that is above 0.90. Also, RMSEA must have a value between 0.40 and 0.80 before it can be deemed acceptable and given the value of 0.053 as shown in Table 2 , then the assumption for assessing model fitness for this study is not violated.

\section{Hypotheses testing}

The fitness of the model was made possible after some items of the variables were deleted such as Covid-19 items had one deleted (COV7), customer satisfaction having seven items had three items deleted (CS4, CS5, CS7), organisational productivity having six items had one item deleted (OP6) and organisational performance having five items had one deleted (OPE1). The study had seven direct and four indirect hypotheses, making it a total of 11 hypotheses (Table 4).

H1 and H2 examined Covid-19 pandemic on supply disruption and organisational productivity and the result shows that Covid-19 pandemic significantly impacts supply disruption for $H 1$ at ( $t$-values $=9.084, \beta=0.561$ at $p=0.005$ ) but not organisational productivity for $H 2$ at (t-values $=-1.794, \beta=-0.061$ at $p=0.073$ ). Hence, $H 1$ is positively supported but $H 2$ is negative and shows no support. $H 1$ aligned with the findings of Gunessee et al. (2017), who state that natural or unforeseen circumstances have the tendency to trigger supply disruption of organisations and thereby impact organisation performance. The result also aligns with the finding of Singh et al. (2020) whose study showed Covid-19

Table 4.

Path model and direct effect

\begin{tabular}{lrrrll}
\hline Hypothesised model & \multicolumn{1}{c}{$\beta$} & $t$-value & $p$-value & Remark & Retained/rejected \\
\hline COV $\rightarrow$ SD H1 & 0.561 & 9.084 & 0.000 & Positive and significant & Retained \\
COV $\rightarrow$ OP H2 & -0.061 & -1.794 & 0.073 & Negative and insignificant & Rejected \\
SD $\rightarrow$ OP H3 & 0.841 & 13.030 & 0.000 & Positive and significant & Rejected \\
OP $\rightarrow$ OPE H5 & 0.176 & 2.250 & 0.024 & Positive and significant & Retained \\
OP $\rightarrow$ CS H6 & -0.078 & -1.565 & 0.118 & Negative and insignificant & Rejected \\
CS $\rightarrow$ OPE H9 & -0.548 & -6.642 & 0.000 & Negative and significant & Rejected \\
SD $\rightarrow$ CS H11 & 1.135 & 10.993 & 0.000 & Positive and significant & Rejected
\end{tabular}

Notes: $p<0.05$; where COV = Covid-19 pandemic; ORP = Organisation performance; $\mathrm{OP}=$ Organisational productivity; $\mathrm{SD}=$ Supply disruption; $\mathrm{CS}$ = Customer satisfaction 
had a positive significant impact on supply disruption. However, the Covid-19 pandemic has no direct impact on organisational productivity, negating the findings of Caliendo and Rossi-Hansberg (2012), whose result revealed the positive influence of international availability of product on the productivity of the firm. Similarly, the result from $H 3$ shows that supply disruption positively significantly impacts organisational productivity at ( $t$-values $=13.030, \beta=0.841$ at $p=0.000)$, hence, the hypothesis is not supported. While H5 and $H 6$ examined organisational productivity on organisation performance and customer satisfaction and the results show that organisational productivity significantly impacts organisation performance at ( $t$-values $=2.250, \beta=0.176$ at $p=0.005$ ) but not customer satisfaction at ( $t$-values $=-1.565, \beta=-0.078$ at $p=0.005)$ (Table 5).

Hence, $H 5$ is positively supported but $H 6$ is negative and shows no support. $H 6$ aligns with the finding of Anderson et al. (1997) whose study revealed that in most firms the pursuit of customer satisfaction hampers productivity and vice-versa., H9 examined if there is a significant relationship between customer satisfaction and organisation performance and the result shows negative significant support at ( $t$-values $=-6.642, \beta=-0.548$ at $p=0.005$ ) and this could be as a result of the lockdown which affected many organisation supply chain activities that are created to serve customers. Furthermore, H11 examined if there is a significant relationship between supply disruption and customer satisfaction and the result shows a significant positive relationship at ( $t$-values $=10.993, \beta=1.135$ at $p=0.005$ ).

$\mathrm{H} 4$ and $\mathrm{H1O}$ examined if there is a significant indirect relationship between supply disruption and organisation performance and customer satisfaction as mediated by organisational productivity and the results of $H 4$ and $H 1 O$ show a negative significant indirect effect and a negative insignificant effect, respectively. Hence, organisational productivity mediated the relationship between supply disruption and organisation performance and customer satisfaction negatively. Furthermore, $H 7$ and $H 8$ examined if there is a significant indirect impact between the Covid-19 pandemic and organisation performance and customer satisfaction. The results show that $H 7$ has a negative and significant indirect effect, while $H 8$ shows a positive significant indirect effect between the Covid-19 pandemic and customer satisfaction, which aligns with the findings of Macdonald and Corsi (2013) whose results proved that after experiencing rare severe events, motivating firms sometime go far and beyond to please customers, in a bid to show gratitude for sticking with the brand in difficult times (Figure 2).

\section{Discussion of findings}

The study is the first of its kind to examine supply disruption in the wake of the Covid-19 crisis and organisational performance as mediated by organisational productivity and customer satisfaction. This study becomes very important knowing fully well the extent of the disruption that the Covid-19 pandemic has had on firms' supply chain activities and the

\begin{tabular}{lrcll}
\hline Hypothesised model & Effect & $p$-value & Remark & Retained/rejected \\
\hline $\mathrm{SD} \rightarrow \mathrm{OP} \rightarrow$ OPE H4 & -0.438 & 0.001 & Negative and indirect effect & Retained \\
$\mathrm{COV} \rightarrow \mathrm{OP} \rightarrow$ OPE H7 & -0.259 & 0.000 & Negative and indirect effect & Retained \\
$\mathrm{COV} \rightarrow \mathrm{OP} \rightarrow$ CS H8 & 0.472 & 0.001 & Positive and indirect effect & Rejected \\
$\mathrm{SD} \rightarrow \mathrm{OP} \rightarrow$ CS H1O & -0.065 & 0.508 & Negative and insignificant effect & Rejected
\end{tabular}

Notes: $p<0.05$; where COV = Covid-19 pandemic; ORP = Organisation performance; OP = Organisational productivity; $\mathrm{SD}=$ Supply disruption; $\mathrm{CS}=$ Customer satisfaction

Table 5.

Path model and indirect effects

\section{Wake of \\ COVID-19 \\ crisis}

329

329


JHASS

3,5

\section{0}

Figure 2.

Standardised path model

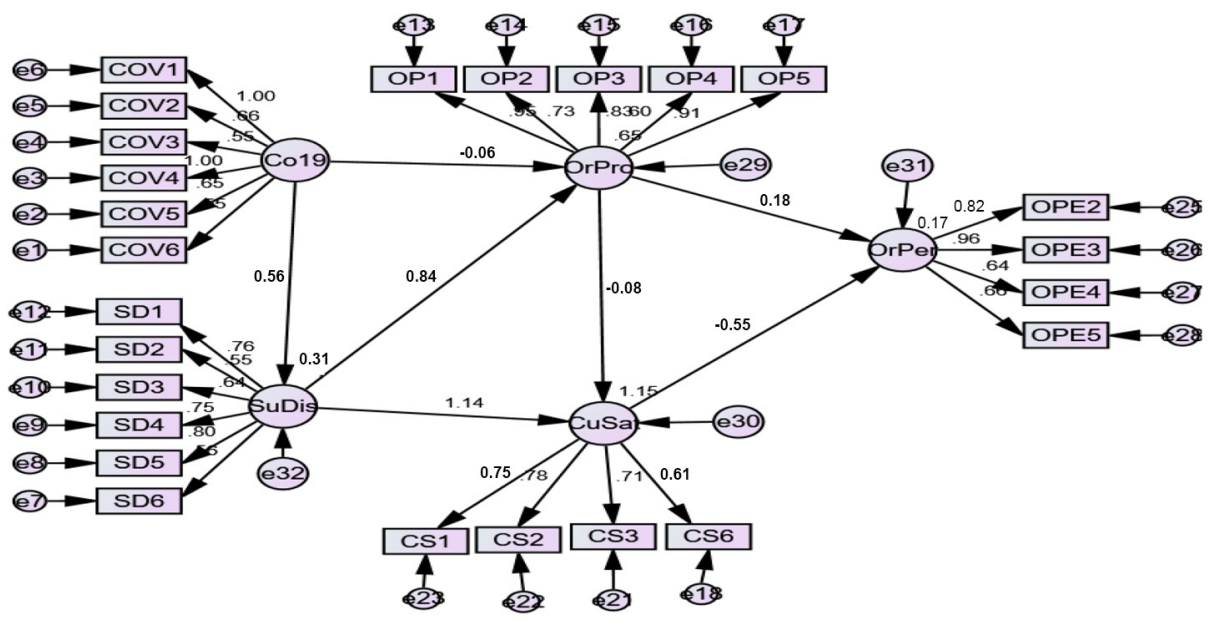

relative effect on firm productivity and customer satisfaction. In total, 11 hypotheses were proposed for this study with seven direct and four indirect hypotheses as in-sighted from literature and the findings show that eight hypotheses were statistically significant, while three were insignificant. That said, based on the direction of proposed hypotheses, four hypotheses were supported and seven were not. Rejected hypotheses may be a reflection of certain factors not considered in this study.

The findings of the study show that supply disruption is inevitable in the wake of the Covid-19 pandemic, hence, its effect on organisational performance. This effect is evident in the firm's productivity, performance, customer-satisfaction and eventual survival of firms in the industry. Although, numerous literature support the findings of $H 1, H 2, H 7$ and $H 8$ with regard to the possibility of unforeseen events such as the Covid-19 pandemic having a significant direct and indirect effect on the supply chain activities of an organisation, its productivity, customer satisfaction and the overall performance of firms. The negative insignificant result of $\mathrm{H} 2$ for this study directly contrasts with the work of Ikon and Chika (2017). However, Babatunde (2020) argued that a significant disruption in the supply of an organisation will have an adverse effect on the organisation so much that it may lead to the eventual closure of such a business organisation. This finding directly relates to the findings of this study for $\mathrm{H3}, \mathrm{H} 4, \mathrm{H} 1 \mathrm{O}$ and $\mathrm{H} 11$ as the findings of the study shows that supply disruption has significant direct and indirect effects on firm productivity, customersatisfaction and firm performance and give credence to the theoretical framework of this study such that the disruption of this magnitude as experienced by many firms in the wake of Covid-19 pandemic is practically an external factor that is beyond the control of the firm management.

Similarly, H5 shows that a significant positive relationship exists between firm productivity and firm performance and directly corroborate the work of (Ali et al., 2011; Dresh et al., 2018), who states that firm productivity is one of the significant measures of firm performance and if not properly cared and catered for in the organisation may affect significantly the overall performance of the firm. Furthermore, customer satisfaction H9 is another important measure of firm performance (Nkengasong and Mankoula, 2020), and as findings showed in the study that there is a significant negative relationship between customer satisfaction and firm performance. The negative relationship is, however, in 
contrast with the submission in some works (Caliendo and Rossi-Hansberg, 2012; Nkengasong and Mankoula, 2020). Finally, findings for $H 6$ show an insignificant negative relationship between organisational productivity and customer satisfaction and although contrast with many findings in the literature that state that organisational productivity has a significant positive relationship with customer satisfaction (Ikon and Chika, 2017). The result for $\mathrm{H} 6$ could be as a result of the Covid-19 pandemic that caused a global lockdown of the economy and restriction of movement of people and proper functioning and continuous operations of many organisations leading to temporary openings of firms considered to be essential producers of goods and services necessary for every-day living.

With regard to organisational productivity and customer satisfaction serving as a mediated relationship between supply disruption and organisational performance. The findings from the study show a positive and negative indirect mediated relationship amongst variables leading to the acceptance of three proposed mediated hypotheses. Overall, the findings of the study have theoretical implications as posited in this study such that every organisation exist within a functional system and is controlled by both internal and external forces and most external events like the Covid-19 pandemic are mostly beyond the control of an organisation (Teece, 2018; Cordon, 2013). These external occurrences are usually dealt with by organisation via dynamic resilience strategies put in place by the organisation to curb the adverse effect of an unforeseen event such as the Covid-19 pandemic that may negatively affect firm operations and continuous survival in the industry.

\section{Conclusion, implications and further research}

Supply disruption in the wake of the Covid-19 pandemic is an inevitable occurrence to firms all over the world and the major determinant of continuous operations and survival of firms especially for small and medium firms will be the ability to remain productive in the wake of an event as severe as the Covid-19 pandemic. Findings from the study have been able to harmonise with empirical literature regarding the effect of unforeseen events such as the Covid-19 pandemic on supplies and other organisational facets.

\section{Research implications}

This study is the first to examine the relationship between the variables under study and provides a path for other researchers to investigate the relationship amongst the variables. Though customer satisfaction was expected to be affected by the pandemic, it is interesting to find out that customer satisfaction when mediated by organisational productivity was positively influenced, this could be those extra efforts by organisations to satisfy the customers, being cognisant of the depleted disposable income of customers and the scramble for the few who have purchasing power. This study empirically tests the relationship amongst Covid-19, supply disruption, organisational productivity, customer satisfaction and organisational performance and it reveals that firms can achieve customer satisfaction despite the challenges faced, though this has not translated into better performance. However, it is expected that if customer satisfaction is sustained, when the economy becomes vibrant again and disposable income is higher, organisational performance will improve and customer loyalty would be secured. In addition, the conceptual model in this study is unique and should be tested on different forms and sizes of businesses. 


\section{JHASS 3,5}

\section{Managerial implications}

Supply disruptions are technically beyond the control of the firm in some cases, as revealed by the current pandemic. Managers must balance the scale of the pursuit of customer satisfaction and productivity so that one does entirely sacrifice the other. As revealed by the $H 6$ result and Anderson et al. (1997) the pursuit of absolute CS will diminish productivity. Emphasis must be channelled towards managing the productivity of the firm to maintain customer satisfaction during these uncertain times. Practically, an offsite customer complaint team should be enacted to collate customer complaints and address them, to prevent distraction and diversion of manpower onsite towards addressing customer complaints. This will ensure customers do not feel their concern is relegated, and their satisfaction is maintained during these times as seen in H11; while managing commendable productivity levels. In addition, deliberate steps can be taken to ensure that when disruption occurs, the organisation can continue to function and satisfy its customers. This will be a direct response to $H 1, H 2$ and $H 3$. Efforts in production and labour flexibility must be made to ensure disruptions do not ground the firm. Production flexibility enables a firm produce a range of products from the same floor with a minimal equipment change, while labour flexibility ensures the labour force (especially machine operators) is abreast with several systems, machines and tasks (Stevenson and Spring, 2007).

A car production/assembly plant that almost seamlessly switches its production to ventilators (medical appliances) for the time being is evidence of investment in production flexibility. While it shifts the customer base, it ensures the firm remains in business and is highly relevant as ventilators are in very high demand globally. Also, machine flexibility should be considered moving forward, as it deals with a machine being capable of producing with more than one input (Jain et al., 2013). Practically, organisations that rely exclusively on wheat flour should invest in configuring their machine to be capable of producing cassava flour (or other flours), as that could be more accessible (in Nigeria). This is taking cognisance of the fact that an international supply disruption (which could be triggered by a plethora of circumstances) will hamper the importation of wheat flour. Manufacturing flexibility is applicable to several manufacturing industries. In addition, initiating an IT system that enables non-production floor workers to work from home would support operational flexibility and prevent a total breakdown when the government insists on minimal staff presence in manufacturing firms. Also, a comprehensive IT system would enable accurate and real-time information synchronisation for faster and better decision-making in uncertain circumstances (Stevenson and Spring, 2007). All these cannot be done without labour flexibility, as it ensures training and exposure to all these equipment, different machine configurations and processes in anticipation of rapid adaptability and a need for resilience. An investment into a more flexible system internally and across the supply chain is recommended to keep the organisation a step ahead of any future disruption that may occur.

\section{Suggestions for further research}

The study examined supply disruption in the wake of the Covid-19 crisis and organisational performance as mediate d by organisational productivity and customer satisfaction by selecting respondents from manufacturing firms in Nigeria. Further research can be done on the same subject matter by extending the sample framework beyond the 898 sample sizes and beyond Nigeria as a whole. Also, the study focus is specifically on manufacturing firms, hence, further research can be conducted to extend to other business sectors to have a holistic view of the effect of the Covid-19 pandemic and the disruption it has caused in other business sectors. Further research can also be done to look at a comparative impact of the Covid-19 pandemic and supply disruption on organisation performance in developed and 
developing economies. This would serve as an insight to government all over the world especially in developing economies such as Nigeria about the importance of creating an enabling business environment that can support firms to withstand external or unforeseen crises such as the Covid-19 pandemic.

\section{References}

Addison, J.T. and Hirsh, B.T. (1989), "Union effects on productivity, profits, and growth: has the long run arrived?", Journal of Labor Economics, Vol. 7 No. 1, pp. 72-105.

Ali, S.I., Yousof, J., Khan, M.R. and Massod, S.A. (2011), "Evaluation of performance in manufacturing organisation through productivity and quality", African Journal of Business Management, Vol. 5 No. 6, pp. 2211-2219.

Alonso, A.D., Kok, S.K., Bressan, A., O'Shea, M., Sakellarios, N., Koresis, A., Solis, M.A.B. and Santoni, L.J. (2020), "COVID-19, aftermath, impacts, and hospitality firms: an international perspective", International Journal of Hospitality Management, Vol. 91, pp. 1-11.

Amin, M., Ismail, K.W., Rasid, Z.A.S. and Selemani, D.A.R. (2014), "The impact of human resource management practices on performance: evidence from a public university", The TQM Journal, Vol. 26 No. 2, pp. 125-142.

Anderson, E.W., Fornell, C. and Rust, R.T. (1997), "Customer satisfaction, productivity, and profitability: differences between goods and services", Marketing Science, Vol. 16 No. 2, pp. 129-145.

Babatunde, A.I. (2020), "Impacts of COVID 19 on supply chain operations in Nigeria", International Journal of Business and Management Invention (IJBMI), Vol. 9 No. 4, pp. 43-53.

Bayo-Moriones, A., Billon, M. and Lera-Lopez, F. (2013), "Perceived performance effects of ICT in manufacturing SMEs", Industrial Management and Data Systems, Vol. 113 No. 1, pp. 117-135.

Bertalanffy, L.V. (1972), "The history and status of general systems theory", The Academy of Management Journal, Vol. 15 No. 4, pp. 407-426.

Boulding, K.E. (1956), "General systems theory - the skeleton of science”, Management Science, Vol. 2 No. 3, pp. 197-208.

Business Continuity Institute (2011), "Business continuity institute survey reveals the high levels and deep-rooted nature of supply chain failure", available at: www.thebci.org (accessed 18 June 2020).

Business Continuity Institute (2013), "Supply chain resilience 2013, 5th annual survey", available at: www.bcifiles.com/131029SupplyChainSurveyReportfinallowres.pdf (accessed 12 July 2020).

Business Continuity Institute (2018), "Supply chain failure closes more than half of KFC fast-food outlets", available at: www.thebci.org/news/supply-chain-failure-closes-more-than-half-of-kfcfast-food-outlets.html (accessed 10 July 2020).

Caliendo, I. and Rossi-Hansberg, E. (2012), "The impact of trade on organisation and productivity”, The Quarterly Journal of Economics, Vol. 127 No. 3, pp. 1393-1467.

Chaudhuri, A., Boer, H. and Taran, Y. (2018), "Supply chain integration, risk management and manufacturing flexibility", International Journal of Operations and Production Management, Vol. 38 No. 3, pp. 690-712.

Chavez, R., Yu, W., Feng, M. and Wiengarten, F. (2016), "The effect of customer-centric green supply chain management on operational performance and customer satisfaction”, Business Strategy and the Environment, Vol. 25 No. 3, pp. 205-220.

Cordon, C.P. (2013), "System theories: an overview of various system theories and its application in healthcare”, American Journal of Systems Science, Vol. 2 No. 1, pp. 13-22. 
Deloitte (2020), “COVID-19: managing supply chain risk and disruption”, available at: www2.deloitte. com/global/en/pages/risk/articles/covid-19-managing-supply-chain-risk-and-disruption (accessed 29 April 2020).

Devor, E.R., Chang, T. and Sutherland, W.J. (1992), Statistical Quality Design and Control: Contemporary Concepts and Methods, Macmillan Publishing Company, New York, NY.

Dresh, A., Veit, D.R., Lima, P.N., Lacerda, D.P. and Collato, D.C. (2018), "Inducing Brazilian manufacturing SMEs productivity with lean tools", International Journal of Productivity and Performance Management, Vol. 68 No. 1, doi: 10.1108/IJPPM-10-2017-0248.

Emrah, C. (2010), "Measuring customer satisfaction: must or not?", Journal of Naval Science and Engineering, Vol. 6 No. 2, pp. 76-88.

Field, A.P. (2005), Discovering Statistics Using SPSS, 2nd ed., Sage Publications, London.

Giese, J.L. and Cote, J.A. (2000), "Defining consumer satisfaction”, Academy of Marketing Science Review, Vol. 1 No. 1, pp. 1-24.

Grayson, K., Nyamazana, M. and Funjika-Mulenga, P. (2016), "Management quality, productivity, and profitability in Zambia", Working paper for the International Growth Centre, London School of Economic and Political Science, London, available at: www.theigc.org/wp-content/uploads/2016/ 11/Grayson-et-al-2016-working-paper.pdf (accessed 12 August 2020).

Gruber-Muecke, T. and Hofer, K.M. (2015), "Market orientation, entrepreneurial orientation and performance in emerging markets", International Journal of Emerging Markets, Vol. 10 No. 3, pp. 560-571.

Gu, J.W. and Jung, H.W. (2013), "The effects of is resources, capabilities, and qualities on organisational performance: an integrated approach", Information and Management, Vol. 50 No. 2, pp. 87-97.

Gunessee, S., Subramanian, N. and Ning, K. (2017), "Natural disasters, PC supply chain and corporate performance", International Journal of Operations and Production Management, doi: 10.1108/ IJOPM-12-2016-0705.

Gustaffsson, A., Johnson, D.M. and Roos, I. (2005), "The effects of customer satisfaction, relationship commitment dimensions and the triggers on customer retention", Journal of Marketing, Vol. 69 No. 4, pp. 210-218.

Hendricks, K.B. and Singhal, V.R. (2003), "The effect of supply chain glitches on shareholder wealth", Journal of Operations Management, Vol. 21 No. 5, pp. 501-522.

IBIS (2020), "Pharmaceutical raw materials", available at: www.ibisworld.com/china/market-researchreports/pharmaceutical-raw-material-manufacturing-industry (accessed 10 May 2020).

Ikon, M.A. and Chika, C.A. (2017), "Production constraints in recession: a study of selected quoted pharmaceutical companies in Nigeria", European Journal of Business and Innovation Research, Vol. 5 No. 5, pp. 1-12.

Ivanov, D. (2020), "Predicting the impacts of epidemic outbreaks on global supply chains: a simulationbased analysis on the coronavirus outbreak (COVID-19/SARS-CoV-2) case", Transportation Research Part E, Vol.136, pp. 1-14.

Ivanov, D., Doglui, A., Sokolov, B. and Ivanova, M. (2017), "Literature review on disruption recovery in the supply chain", International Journal of Production Research, Vol. 55 No. 20, doi: 10.1080/ 00207543.2017.1330572.

Jain, A., Jain, P.K., Chan, F.T.S. and Singh, S. (2013), "A review on manufacturing flexibility", International Journal of Production Research, Vol. 51 No. 19, pp. 5946-5970.

Jenkins, R. (2012), “China and Brazil: economic impacts of a growing relationship”, Journal of Current Chinese Affairs, Vol. 41 No. 1, pp. 21-47.

Jüttner, U. and Maklan, S. (2011), "Supply chain resilience in the global financial crisis: an empirical study", Supply Chain Management: An International Journal, Vol. 16 No. 4, pp. $246-259$. 
Khan, J.H. (2003), "Impact of total quality management on productivity", The TQM Magazine, Vol. 15 No. 6, pp. 374-380.

Khan, A.A. and Hashim, H. (2020), "Tourist satisfaction index for tourism destination, integrating social media engagement into the European customer satisfaction index: a conceptual paper", International Journal of Academic Research in Business and Social Sciences, Vol. 10 No. 9, pp. 72-90.

Kim, D.Y., Kumar, V. and Kumar, U. (2012), "Relationship between quality management practices and innovation", Journal of Operations Management, Vol. 30 No. 4, pp. 295-315.

KPMG (2016), "Wheat-based consumer foods in Nigeria", available at: https://home.kpmg/ng/en/ home/insights/2016/08/wheat-based-consumer-foods-in-nigeria.html (accessed 11 August 2020).

Kumar, S., Liu, J. and Scutella, J. (2015), "The impact of supply chain disruptions on stockholder wealth in India", International Journal of Physical Distribution and Logistics Management, Vol. 45 Nos 9/10, pp. 938-958.

Kumar, A., Luthra, S., Mangla, S.K. and Kazancolu, Y. (2020), "COVID-19 impact on sustainable production and operations management", Sustainable Operations and Computers, Vol. 2020 No. 1, pp. 1-7.

Lakhal, L., Pasin, F. and Limam, M. (2006), "Quality management practices and their impact on performance", International Journal of Quality and Reliability Management, Vol. 23 No. 6, pp. 625-646.

Lee, J.J., Patterson, P.G. and Ngo, L.V. (2017), "In pursuit of service productivity and customer satisfaction: the role of resources", European Journal of Marketing, Vol. 51 Nos 11/12, pp. 1836-1855, doi: 10.1108/EJM-07-2016-0385.

McKinsey Global Institute (2019), "China and the world: inside the dynamics of a changing relationship", available at: www.mckinsey.com/mgi (accessed 15 August 2020).

Macdonald, J.R. and Corsi, T.M. (2013), "Supply chain disruption management: severe events, recovery, and performance", Journal of Business Logistics, Vol. 34 No. 4, pp. 270-288.

Madrid, G.A., Auken, H. and García, P.D. (2007), "An analysis of factors impacting performance of Spanish manufacturing firms", Journal of Small Business and Entrepreneurship, Vol. 20 No. 4, pp. 369-379.

Marley, K.A., Ward, P.T. and Hill, J.A. (2014), "Mitigating supply chain disruptions - a normal accident perspective”, Supply Chain Management: An International Journal, Vol. 19 No. 2, pp. 142-152.

Martins, S.M., Miguel, P.L.S., Brito, R.P. and Pereira, S.C.F. (2019), "Supply chain resilience: the whole is not the sum of the parts", International Journal of Operations and Production Management, doi: 10.1108/IJOPM-09-2017-0510.

Mele, C., Pels, J. and Polese, F. (2010), "A brief review of systems theories and their managerial applications", Service Science, Vol. 2 Nos 1/2, pp. 126-135, doi: 10.1287/serv.2.1_2.126.

Mishra, R., Ashok, K.P. and Ganapathy, L. (2017), "Evaluation and prioritisation of manufacturing flexibility alternatives using integrated AHP and TOPSIS method: evidence from a fashion apparel firm”, Benchmarking: An International Journal, Vol. 24 No. 5, doi: 10.1108/BIJ-07-20150077.

Murphy, G.B., Trailer, J.W. and Hill, J.W. (1996), "Measuring performance in entrepreneurship research", Journal of Business Research, Vol. 36 No. 1, pp. 15-23.

Natarajarathinam, M., Capar, I. and Narayanan, A. (2009), "Managing supply chains in times of crisis: a review of literature and insights", International Journal of Physical Distribution and Logistics Management, Vol. 39 No. 7, pp. 535-573.

Nkengasong, J.N. and Mankoula, W. (2020), "Looming threat of COVID-19 infection in Africa: act collectively, and fast", The Lancet, Vol. 395 No. 10227, pp. 841-842. 
Nusair, K. and Hua, N. (2010), "Comparative assessment of structural equation modeling and multiple regression research methodologies: e-commerce context", Tourism Management, Vol. 31 No. 3, pp. 314-324.

Orçan, F. and Yang, Y. (2016), "A note on the use of item parceling in structural equation modeling with missing data", Journal of Measurement and Evaluation in Education and Psychology, Vol. 7 No. 1, pp. 59-72, doi: 10.21031/epod.88204.

Pereira, C.R., Christopher, M. and Da Silva, A.L. (2014), “Achieving supply chain resilience: the role of procurement”, Supply Chain Management: An International Journal, Vol. 19 No. 5/6, pp. 626-642.

Polyviou, M., Croxton, K.L. and Knemeyer, M.A. (2019), "Resilience of medium-sized firms to supply chain disruptions: the role of internal social capital", International Journal of Operations and Production Management, doi: 10.1108/IJOPM-09-2017-0530.

Queiroz, M.M., Ivanov, D., Dolgui, A. and Wamba, S.F. (2020), "Impacts of epidemic outbreaks on supply chains: mapping a research agenda amid the COVID-19 pandemic through a structured literature review", Annals of Operations Research, doi: 10.1007/s10479-020-03685-7.

Revilla, E. and Saenz, M.J. (2017), "The impact of risk management on the frequency of supply chain disruptions: a configurational approach", International Journal of Operations and Production Management, Vol. 37 No. 5, pp. 557-576.

Sadikoglu, E. and Olcay, H. (2014), "The effects of total quality management practices on performance and the reasons of and the barriers to TQM practices in Turkey", Advances in Decision Sciences, Vol. 2014, doi: 10.1155/2014/537605.

Shahiduzzaman, M., Kowalkeiwicz, M. and Barrett, R. (2017), "Digital dividends in the phase of falling productivity growth and implications for policy making”, International Journal of Productivity and Performance Management, doi: 10.1108/IJPPM-02-2017-0050.

Shehzadi, S., Nisar, Q.A., Hussain, M.S., Basheer, M.F., Hameed, W.U. and Chaudhry, N.I. (2020), "The role of digital learning toward students' satisfaction and university brand image at educational institutes of Pakistan: a post-effect of COVID-19", Asian Education and Development Studies, doi: 10.1108/AEDS-04-2020-0063.

Shen, D. (2008), "What's happening in China's textile and clothing industries?", Clothing and Textiles Research Journal, Vol. 26 No. 3, pp. 203-222.

Shen, H., Fu, M., Pan, H., Yu, Z. and Chen, Y. (2020), "The impact of the Covid-19 pandemic on firm performance", Emerging Markets Finance and Trade, Vol. 56 No. 10, pp. 2213-2230, doi: 10.1080/ 1540496X.2020.1785863.

Singh, S., Kumar, R., Panchal, R. and Tiwari, M.K. (2020), "Impact of COVID-19 on logistics systems and disruptions in food supply chain", International Journal of Production Research, doi: 10.1080/00207543.2020.1792000.

Stevenson, M. and Spring, M. (2007), "Flexibility from a supply chain perspective: definition and review", International Journal of Operations and Production Management, Vol. 27 No. 7, pp. 685-713.

Tang, O. and Musa, N. (2011), "Identifying risk and research advancements in supply chain risk management”, International Journal of Production Economics, Vol. 133 No. 1, pp. 25-34.

Tanninen, K., Puumalainen, K. and Sandström, J. (2010), "The power of TQM: analysis of its effects on profitability, productivity and customer satisfaction”, Total Quality Management, Vol. 21 No. 2, pp. 171-184.

Tarí, J.J., Molina, J.F. and Castejon, J.L. (2007), "The relationship between quality management practices and their effects on quality outcomes", European Journal of Operational Research, Vol. 183 No. 2 , pp. 483-501.

Teece, D.J. (2018), "Dynamic capabilities as (workable) management systems theory", Journal of Management and Organisation, Vol. 24 No. 3, pp. 359-368. 
Tse, Y.K., Matthews, R.L., Tan, K.H., Sato, Y. and Pongpanich, C. (2016), "Unlocking supply chain disruption risk within the Thai beverage industry", Industrial Management and Data Systems, Vol. 116 No. 1, pp. 21-42.

Udofia, E.E. (2019), "Understanding quality management and customer satisfaction: a necessity", European Journal of Applied Business Management, Vol. 5 No. 4, pp. 1-16.

United Nation (2019), "National accounts-analysis of main aggregates (AMA)", available at: www. unstats.un.org/unsd/snaama (accessed July 14, 2020).

United Nations Conference on Trade and Development (UNCTAD) (2020), "Global trade impact of the coronavirus (covid-19) epidemic”, available at: https://unctad.org/publication (accessed 17 July 2020).

Vasić, N., Kilibarda, M. and Kaurin, T. (2019), "The influence of online shopping determinants on customer satisfaction in the Serbian market", Journal of Theoretical and Applied Electronic Commerce Research, Vol. 14 No. 2, pp. 70-89.

Wakeel, I.A. and Ekundayo, M.P. (2016), "Determinants of pharmaceutical industry's performance in Nigeria”, Managing Global Transitions, Vol. 14 No. 3, pp. 267-282.

Yan, J., Zhang, K., Zhu, W. and Fan, Y. (2019), "An empirical framework for soft CSFs of TQM in Chinese manufacturing companies”, The TQM Journal, Vol. 31 No. 3, doi: 10.1108/TQM-07-20180102 .

Yana, A. (2007), "High-performance global account management teams: design dimensions, processes and outcomes", Doctoral dissertation, University of St. Gallen, available at: www1.unisg.ch/www/edis.nsf/SysLkpByIdentifier/3324/\$FILE/dis3324.pdf (accessed 14 August 2020).

Zhang, Z., Waszink, A. and Wijngaard, J. (2000), “An instrument for measuring TQM implementation for Chinese manufacturing companies”, International Journal of Quality and Reliability Management, Vol. 17 No. 7, pp. 730-755.

\section{Further reading}

Kaynak, H. (2003), "The relationship between total quality management practices and their effects on firm performance", Journal of Operations Management, Vol. 21 No. 4, pp. 405-435.

Richard, P.J., Devinney, T.M., Yip, G.S. and Johnson, G. (2008), “Measuring organisational performance as a dependent variable: towards methodological best practice", Journal of Management, Vol. 35 No. 3, pp. 718-804.

\section{About the authors}

Ekpenyong Ekpenyong Udofia is an operations and supply chain management enthusiast, with a BSc in Business Administration and an MSc degree in production and operations management, both from the University of Lagos. He is currently working with a consulting firm in Lagos, Nigeria, as the operations manager, where he is actively involved in management research and consult. He is a Doctoral research scholar with publications in both local and international journal outlets and is interested in research studies in Quality management, Supply chain, Logistics management, Innovation management, Lean manufacturing, Business environment uncertainty, Productivity and New product development. Ekpenyong Ekpenyong Udofia is the corresponding author and can be contacted at: solokoko2003@yahoo.com

Bimbo Onaolapo Adejare is a Master degree (M.Sc. Management) holder from the University of Lagos. He earned his first degree (B.Sc. in Business Administration) at the Osun State University. He is a member of the Nigerian Institute of Management and the Institute of Strategic Management of Nigeria as a Chartered manager and strategic Manager respectively. He is a Doctoral Research Scholar at the University of Minho, School of Economics and Management. He has collaborated on several research works and his area of research interest are but not limited to Entrepreneurship Internalization, Managing Nonmarket Risk, Innovation Management, Firm Dynamic Capabilities, 
JHASS

3,5

Business Model Innovation, Sustainable SMEs development, and Succession Planning. Bimbo Adejare has attended and presented in both local and international conferences.

Gbemi Oladipo Olaore is a graduate of the University of Ado-Ekiti where he bagged a B.Sc. in Business Administration and Management. He proceeded to the University of Lagos and earned his M.Sc. in Business Administration and Management. He is currently a Researcher/PhD Scholar and has published in both local and internationally recognised journals. Area of research interest are but not limited to Entrepreneurship/SMEs Development, International Business, Branding and Rebranding, Sustainable SMEs in the Health Sector, Internationalization, Innovation management, Sustainable SMEs development, Succession Planning, Strategic Management and the role played by institutional environment in Sub-Saharan Africa and emerging economies. He has also attended local and international conferences where he presented research papers.

Etete Ekpenyong Udofia holds a BSc in Chemical Engineering, a master's in process engineering and an MBA degree, all from the University of Lagos, Nigeria. Upon completion of the MSc in management programme, he looks forward to specialising in strategic management with a $\mathrm{PhD}$. He is a Chartered Manager as an Associate member Nigerian Institute of Management (AMNIM) and a chartered engineer with the Council for the Regulation of Engineering in Nigeria (COREN). He is currently practising in both academics and professional fields. He is interested in SME Development, Strategic management, Engineering process management and Supply chain management.

For instructions on how to order reprints of this article, please visit our website: www.emeraldgrouppublishing.com/licensing/reprints.htm Or contact us for further details: permissions@emeraldinsight.com 